$\sin x$

(n)

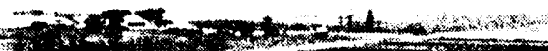
$47 t^{2}$

ar.

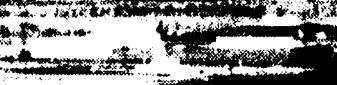
wer at 47 $=x+2=0$ (2) $=0$ $-2-5 x+2$ (n) $+2$

\title{
and
} $-2+2$ $x_{1}$

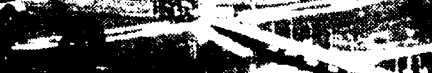 -

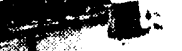
ans (n)

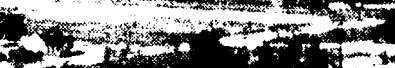

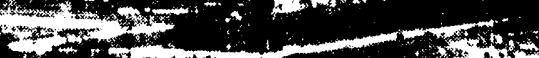

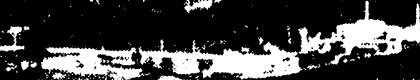

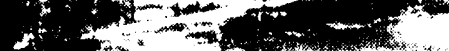

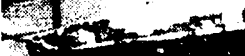
$+\infty$

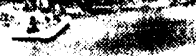

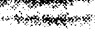

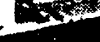
$P=-x^{3}+T^{2}$ 7 tas. - $x_{2}+x^{2}$ 


\section{St. James Marine Terminal Facility Description}

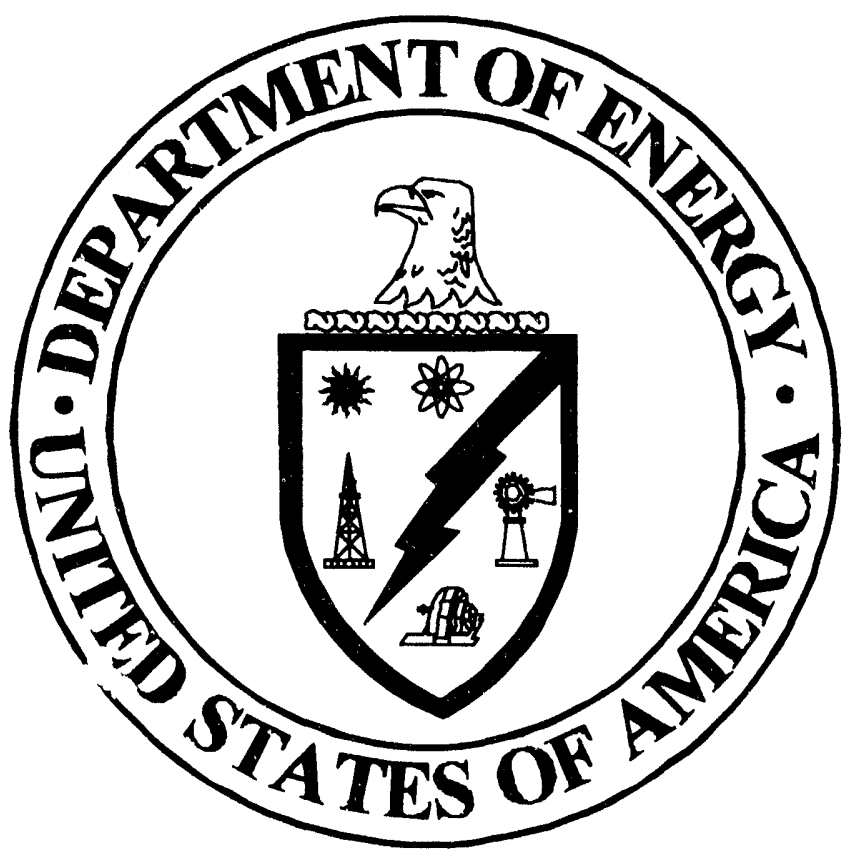

October 1993

\section{U.S. Department of Energy Strategic Petroleum Reserve}




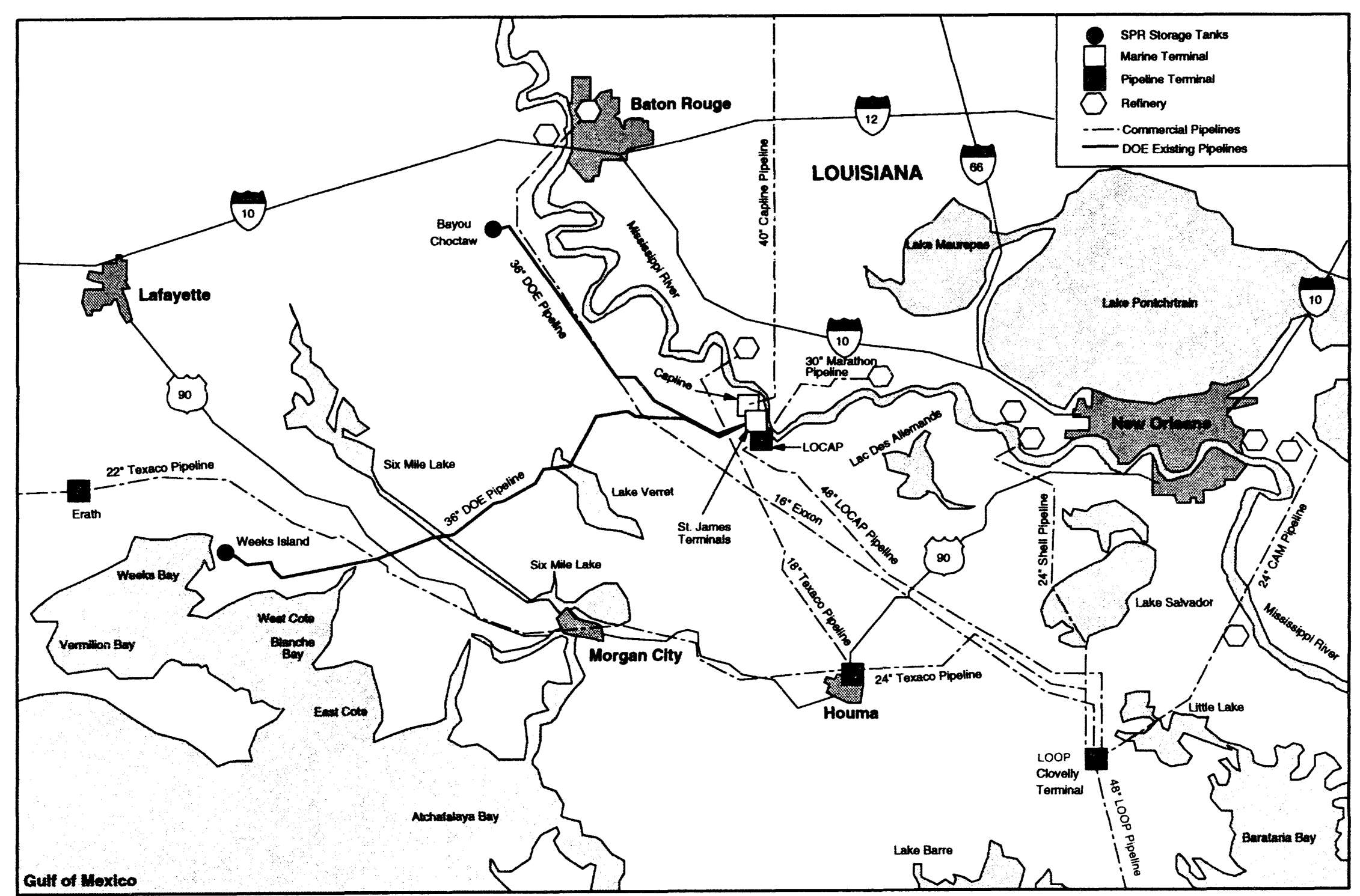

Figure 1. Map Showing General Location of the Strategic Petroleum Reserve's St. James Terminal. 


\section{The Department of Energy's Strategic Petroleum Reserve ST. James Marine Terminal}

\section{INTRODUCTION}

The U.S. Department of Energy (DOE) currently owns and operates a marine terminal on the west bank of the Mississippi River at St. James, Louisiana. The St. James facility was constructed by the Department to provide marine services associated with the fill and drawdown of the Strategic Petroleum Reserve (SPR) crude oil storage facilities located at Bayou Choctaw and Weeks Island, Louisiana. Although strategic to the mission of the SPR in the event of a national emergency, the St. James terminal is situated such that it has a high potential to also serve the commercial industry's needs for crude oil terminalling and storage.

The St. James terminal is located approximately $\mathbf{4 5}$ miles west of New Orleans and $\mathbf{3 0}$ miles southeast of Baton Rouge, and approximately 160 miles upstream from the mouth of the Mississippi River (Figure 1). Construction of the St. James terminal was initiated in 1978 and was completed in 1980. Since then, the terminal has received and transferred over 125 million barrels of crude oil to the SPR sites for storage. For crude oil distribution, the St. James terminal was connected to the neighboring LOCAP terminal by a 0.1 mile 36-inch pipeline in 1981 and to the Capline terminal by a 0.5 mile 30 -inch pipeline in 1988 . The terminal also has a 30 -inch pipeline connection to the Koch oil terminal which was used for initial fill purposes; however, this pipeline has been disconnected and is currently inactive. Figure 2 shows the relative location of the St. James terminal with respect to the neighboring LOCAP, Capline and Koch terminalling facilities. Figure 3 provides an aerial view of the terminal with the LOCAP terminal to the south and the Capline terminal to the north.

A complete description of the St. James terminal facilities, operational capabilities, operational certifications, and future Government requirements are presented in Sections II, III IV, and V respectively.

\section{FACILITY PHYSICAL DESCRIPTION}

The St. James marine terminal is comprised of two sites: a main terminal facility occupying approximately 105 acres of land and the two marine docks on the Mississippi River occupying approximately 48 acres of land. The main terminal consists of six storage tanks totalling two million barrels capacity, crude oil pumping stations, metering stations, and control and maintenance facilities. All St. James terminal facilities are described in detail in the following paragraphs. 


\section{PAGE 3}

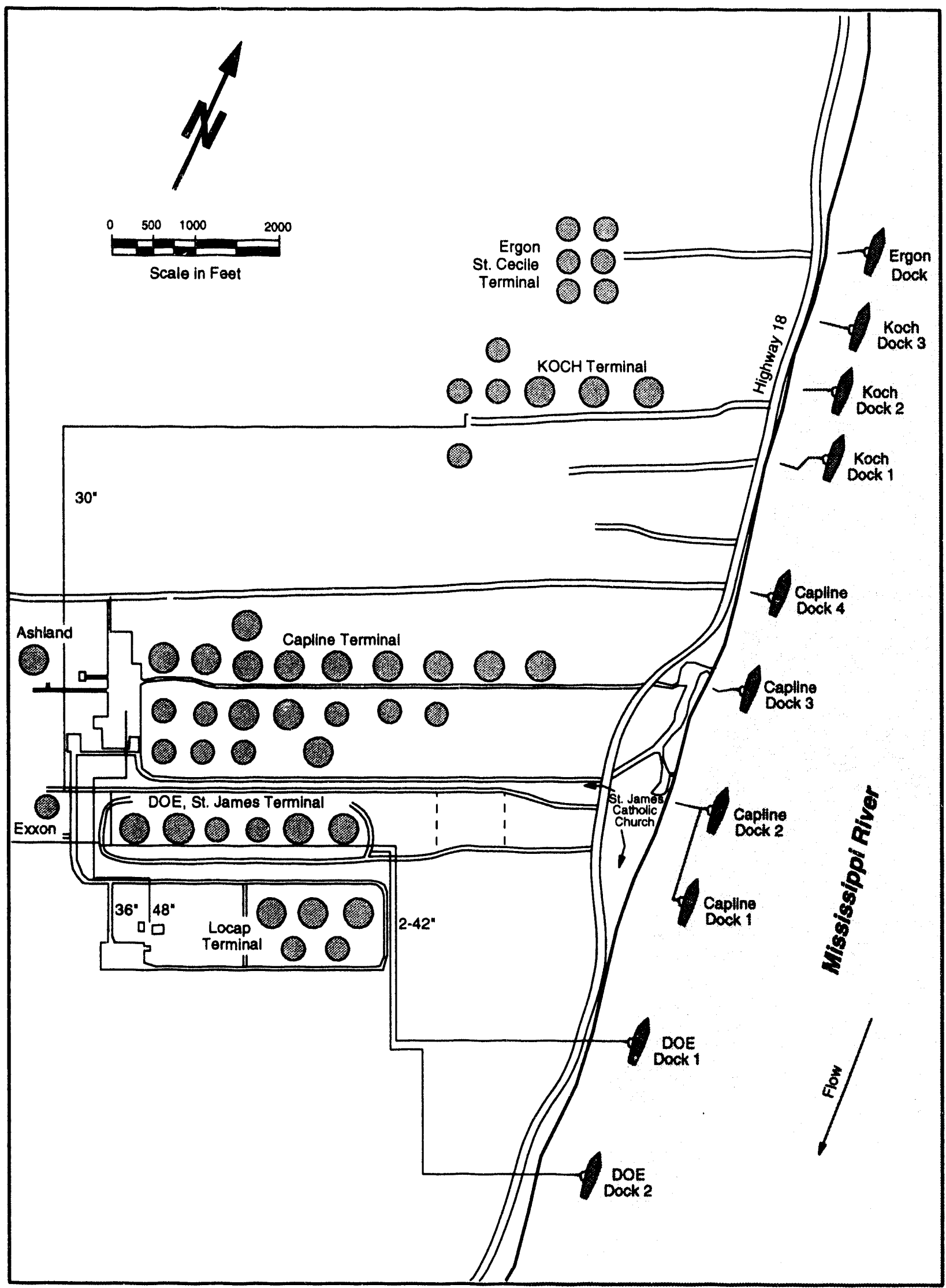

Figure 2. Map of the Local Area Surrounding the Department of Energy's St. James Terminal. 


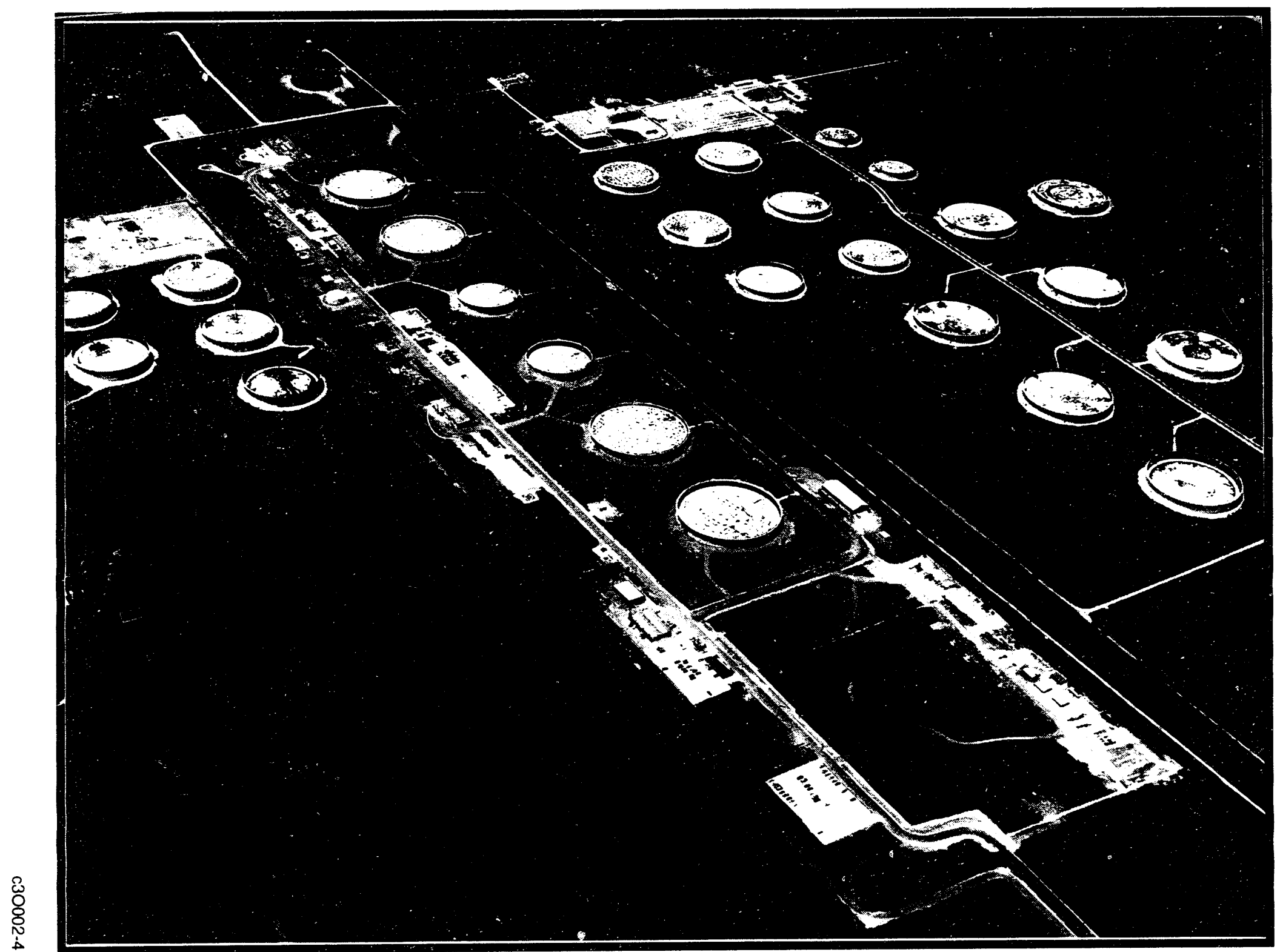

Figure 3: St. James Marine Terminal with LOCAP Terminal (left), and Capline Terminal (right). 


\section{PAGE 5}

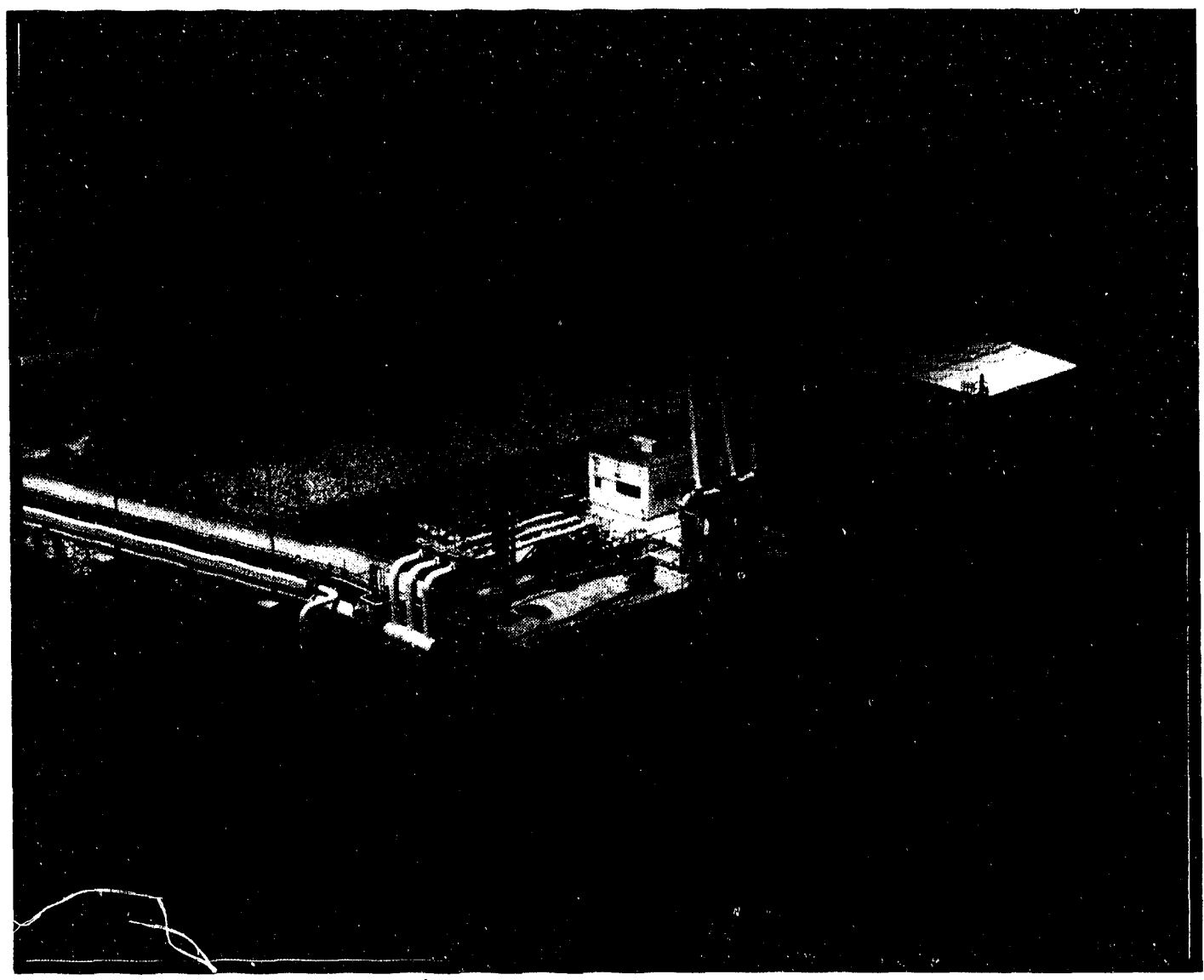

Figure 4: St. James Marine Terminal Dock No. 1 and Fire Water Pump House

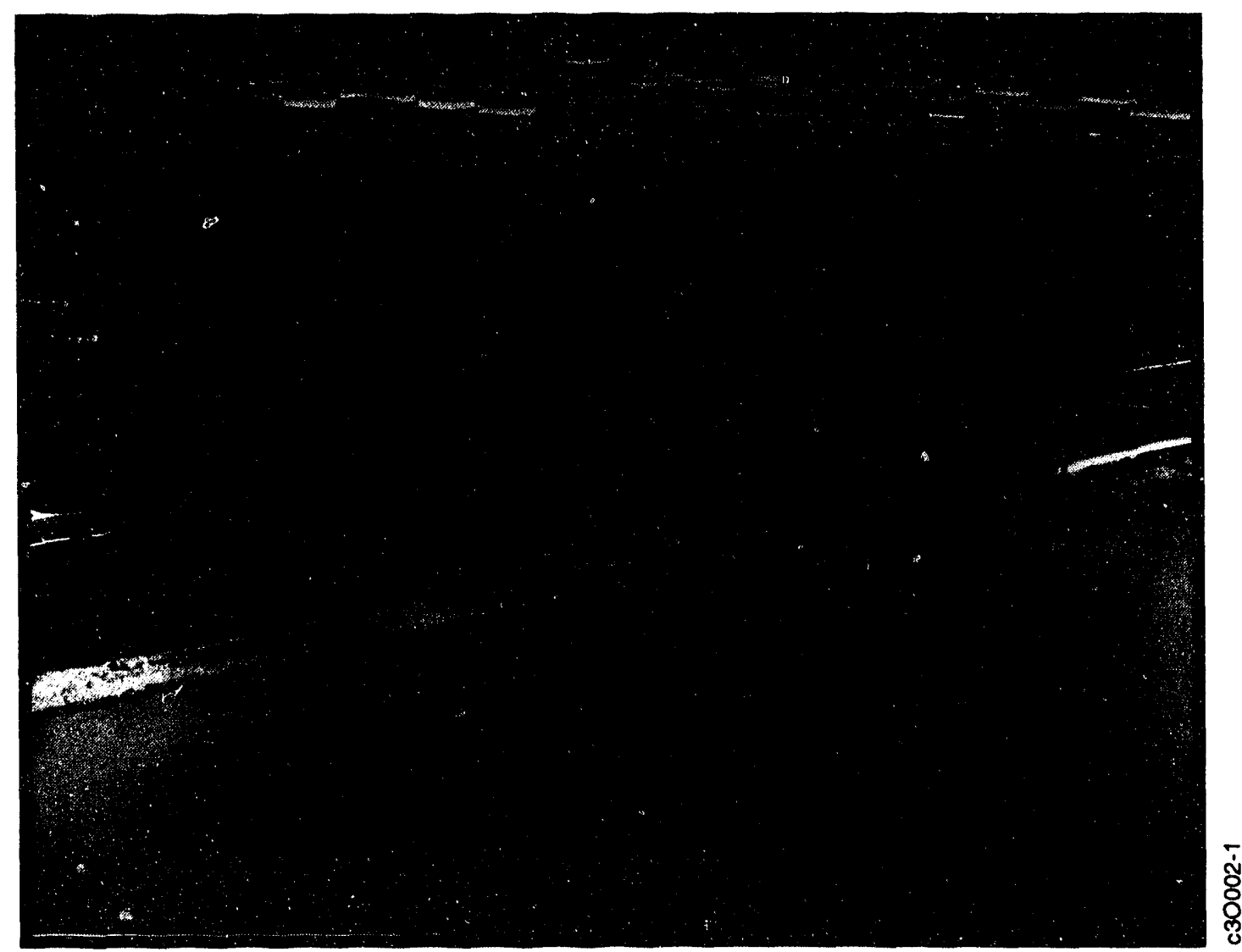

Figure 5: St. James Marine Terminal Dock No. 2 


\section{a. Marine Facilities}

The St. James terminal has two marine docks on the Mississippi River which are located approximately two miles southeast of the main terminal. Dock 1 is located at Mississippi River milepost 158.3, and Dock 2 is located at Mississippi River milepost 158.0. Dock 1 is shown in Figure 4 and Dock 2 is shown in Figure 5.

Both docks are concrete and steel construction with four breasting dolphins and eight mooring dolphins with capstan motors and quick release "pelican hooks". Each dock is equipped with three 16-inch Continental Emsco hydraulic operated loading arms, a 5-ton hydraulic crane, three in-line samplers with positive displacement pumps and manifolded to a single collection pot, and a control room equipped with full emergency shutdown controls.

Each dock is capable of berthing vessels up to 123,000 Dead Weight Tons (DWT), as delineated in Table 1. Normal vessel loading or unloading operations are performed using only two loading arms, with the third arm as a standby spare. During unloading operations, the vessel discharges oil through the loading arms at design flow rates of 40,000 barrels per hour and at pressures ranging from 50-150 psig. Similarly, in loading operations crude oil can be pumped from the storage tanks at the terminal to the docks at design loading rates of 40,000 barrels per hour and 50 psig.

Table 1

St. James Marine Docks Parameters

\begin{tabular}{|c|c|c|c|c|c|c|}
\hline $\begin{array}{c}\text { Tanker } \\
\text { Docks }\end{array}$ & $\begin{array}{c}\text { Maximum } \\
\text { LOA }\end{array}$ & $\begin{array}{c}\text { Maximum } \\
\text { Beam }\end{array}$ & $\begin{array}{c}\text { Maximum } \\
\text { Draft }\end{array}$ & $\begin{array}{c}\text { Maximum } \\
\text { Air Draft }\end{array}$ & $\begin{array}{c}\text { Maximum } \\
\text { DWT }\end{array}$ & $\begin{array}{c}\text { Other } \\
\text { Facilities }\end{array}$ \\
\hline $\begin{array}{c}\text { Dock } \\
\text { No. 1 }\end{array}$ & 940 feet & None & 45 feet & $\begin{array}{c}153 \text { feet } \\
\text { less river } \\
\text { stage }\end{array}$ & 123,000 & $\begin{array}{c}\text {-oily bilge } \\
\text { water } \\
\text {-sludge water }\end{array}$ \\
\hline $\begin{array}{c}\text { Dock } \\
\text { No. 2 }\end{array}$ & 940 feet & None & 45 feet & $\begin{array}{c}153 \text { feet } \\
\text { less river } \\
\text { stage }\end{array}$ & 123,000 & $\begin{array}{c}\text {-oily bilge } \\
\text { water } \\
\text {-sludge water }\end{array}$ \\
\hline
\end{tabular}

Customary Anchorage: Grandview Reach (approximately 11 miles from terminal).

* The terminal does not possess bunkering or deballasting facilities, nor a vapor recovery system.

Both docks are designed for independent and simultaneous operations. Each dock is connected to the main terminal with a 42-inch crude oil line, a 20-inch effluent line, a 6-inch oily water line, and a 2-inch potable water line. The terminal's firewater pumping system is located at Dock 1. 
PAGE 7



Figure 6: St. James Marine Terminal Main Facility. 


\section{b. Terminal Facilities}

The main terminal provides facilities for crude oil storage, pumping, metering and distribution. Figure 6 provides an aerial photograph of the main terminal. An overall site layout of the terminal facilities is shown in Figure 7 and a schematic of the site's internal piping system is shown in Figure 8.

Storage tanks. The St. James terminal has six storage tanks with a total shell capacity of 2 million barrels. These tanks were designed by Graver, Houston, and are constructed on a concrete ring wall and compacted sand base foundation. The tanks are approximately 33 feet high and have a single skin floating roof. Each of the tanks are equipped with Jensen propellertype mixers and temperature and level gauging instrumentation. Storage capacity and specifications are shown in Table 2.

The six tanks are sited in two groups of three, which are each surrounded by a community dike system. Each of the two diked areas could contain the entire volume of one tank with some freeboard allowance. Minor spillage is contained by lower internal dikes between the tanks.

Primary Pump Station. The primary pump station is used to perform all crude oil movements from the terminal's six tanks, whether to the SPR storage sites or the neighboring LOCAP and Capline terminals. These pumps are also designed to pump crude oil from the terminal tanks to the docks for vessel loading operations during an energy emergency.

The primary pump station consists of five Peabody-Floway vertical, deep well, three-stage pumps with a designed capacity at discharge of 25,000 barrels per hour at 288 feet of head each. They are driven by 1500 horsepower Westinghouse moiors. The pump station is manifolded to provide two independent pumping units of two pumps each: Pumps 1 and 2, and Pumps 4 and 5. Pump 3 is manifoided into both systems as an on-line spare. Figure 9 is an aerial photograph of the primary pump station.

Accelerated Fill Pumps. The terminal also has a second pumping station which contains three Bingham Williamette horizontal centrifical pumps rated at 10,000 barrels per hour each at $460 \mathrm{PSI}$ discharge that are driven by 1360 horsepower Louis Allis motors. These pumps are dedicated to the fill of the SPR Weeks Island site and as such are currently manifolded to the Weeks Island delivery system, as shown in Figure 8.

Metering and custody transfer. The terminal has two meter stations which are connected to the Bayou Choctaw and Weeks Island delivery systems respectively. Each meter station consists of three 12-inch meter runs equipped with "Flow Tech" inline turbine meters having a rated capacity of 18,000 barrels per hour each. The meters are calibrated and proved by a unidirectional prover loop adjacent to the meter station. Figure 10 is a photograph of the Weeks Island and Bayou Choctaw meter stations.

The St. James terminal uses tank gauging as its primary custody transfer measurement system for marine receipts and liftings. Each tank has been fully calibrated for accurate measurement. 


\section{PAGE 9}



Figure 7. Site Layout of the St. James Terminal 


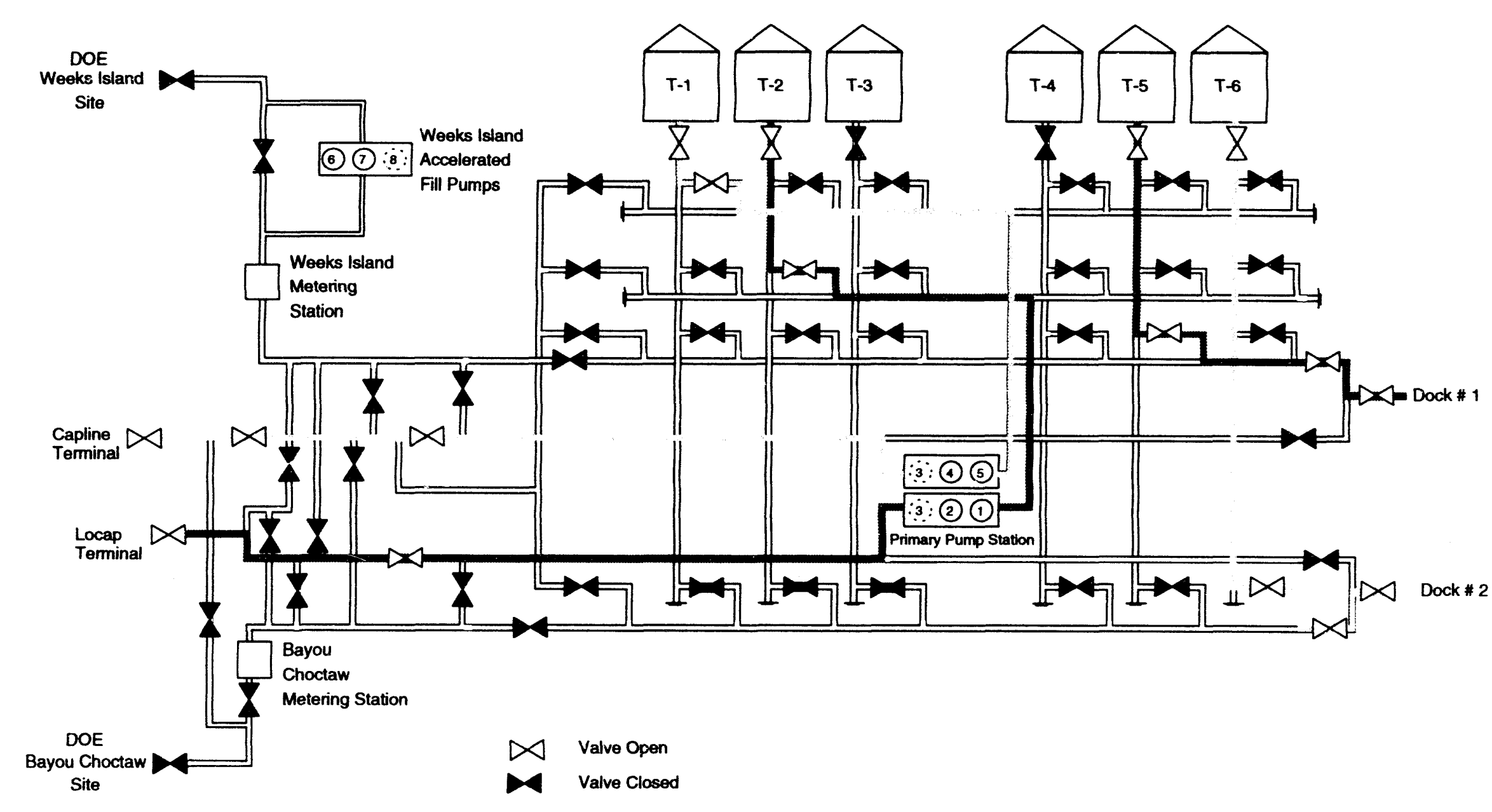

Figure 8. Functional Schematic of St. James Terminal Piping System 


\section{PAGE 11}

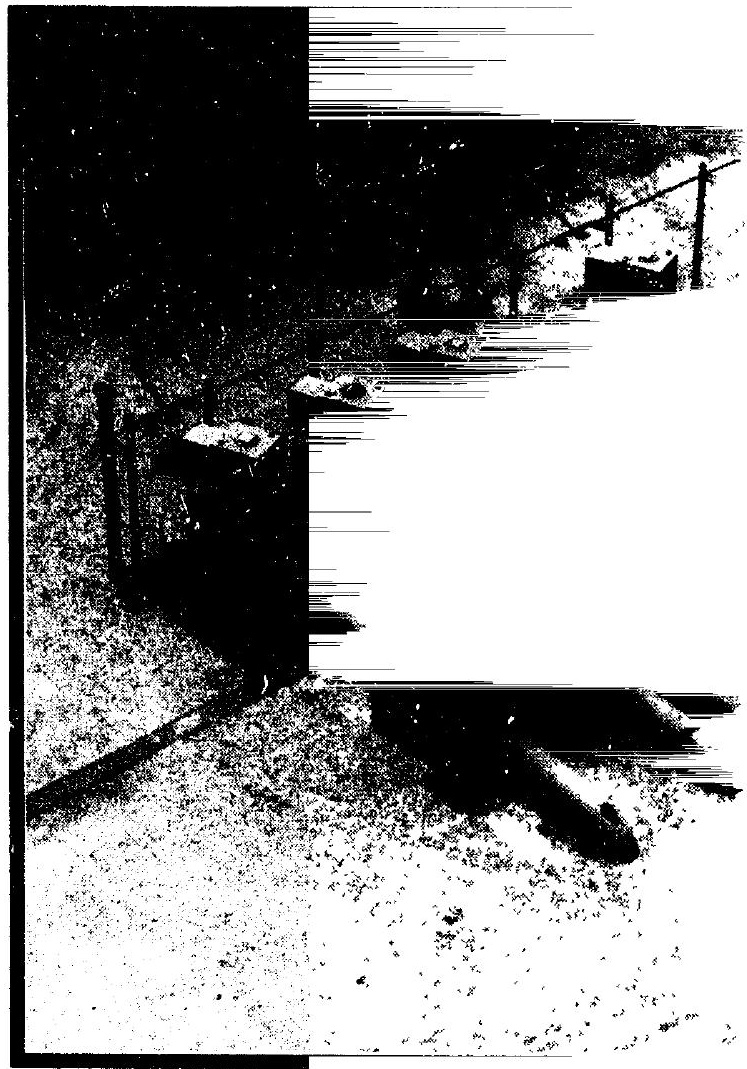

Figure 9: St. James Terminal Primary Pump St

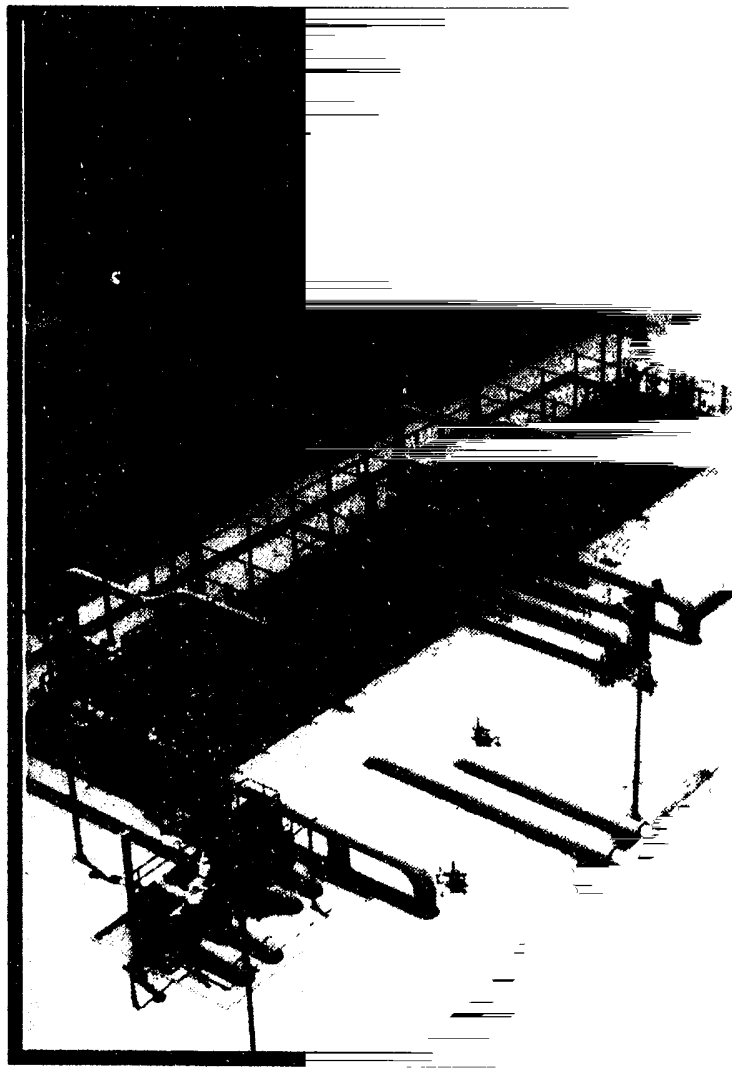

Figure 10: St. James Terminal Weeks Island an 
Table 2

St. James Terminal Storage Tank Specifications

\begin{tabular}{|c|c|c|c|}
\hline $\begin{array}{c}\text { Storage } \\
\text { Tanks }\end{array}$ & Capacity (barrels) & $\begin{array}{c}\text { Size } \\
\text { Diameter } x \text { Height }\end{array}$ & Tank Mixers \\
\hline 1 & 400,000 & $300 \mathrm{ft}^{*} 33 \mathrm{ft}$ & $3-75 \mathrm{hp} \mathrm{mixers}$ \\
\hline 2 & 400,000 & $300 \mathrm{ft}^{*} 33 \mathrm{ft}$ & $3-75 \mathrm{hp}$ mixers \\
\hline 3 & 200,000 & $212 \mathrm{ft}^{*} 33 \mathrm{ft}$ & $2-50 \mathrm{hp}$ mixers \\
\hline 4 & 200,000 & $212 \mathrm{ft}^{*} 33 \mathrm{ft}$ & $2-50 \mathrm{hp}$ mixers \\
\hline 5 & 400,000 & $300 \mathrm{ft}^{*} 33 \mathrm{ft}$ & $3-75 \mathrm{hp}$ mixers \\
\hline 6 & 400,000 & $300 \mathrm{ft}{ }^{*} 33 \mathrm{ft}$ & $3-75 \mathrm{hp}$ mixers \\
\hline
\end{tabular}


PAGE 13

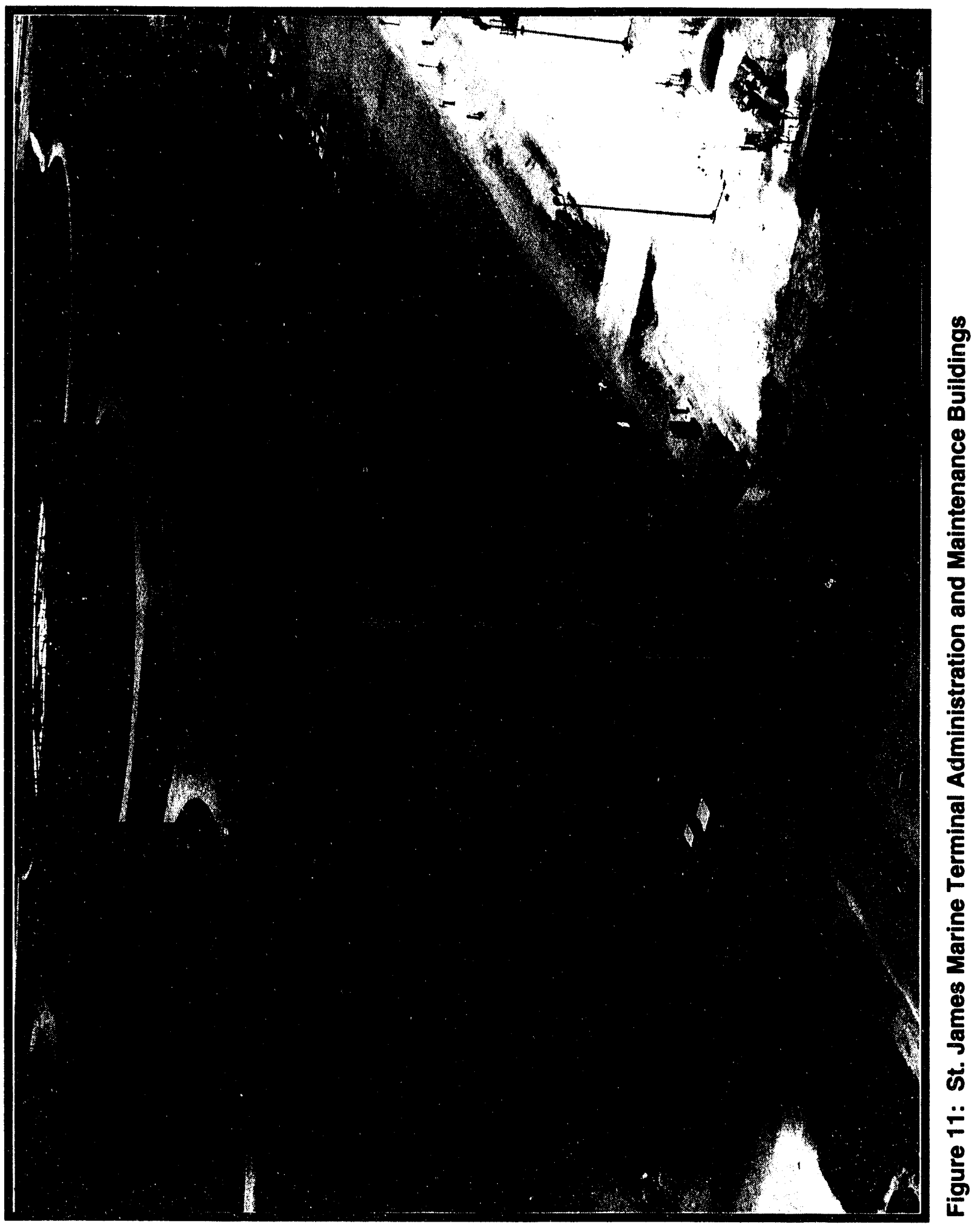

c30002-5 


\section{c. Terminal Buildings}

There are five primary buildings at the St. James terminal: the administration building, the contractor office building, the maintenance building, the spare parts warehouse, and the oil quality assurance laboratory. In addition, there are several minor buildings, such as the security operations center, the effluent treatment building, and the various small buildings for safety and oil spill equipment. The Administration and Maintenance buildings are shown in Figure 11. Layouts of the main buildings may be found in the Appendix.

Administration Building. This building provides office space for the terminal management personnel and houses the Central Control Room and Motor Control Center.

The Central Control Room is the operations center for the terminal. St. James terminal systems are fully automated such that all terminal operations may be conducted from the Central Control Room. Operational commands are given on a Coggins/Intel MDS-210 computer system with data displayed visually and with hard copy. An annunciator panel provides audio and visual alarms to alert operators to any operational changes or problems. A graphic display panel provides a visual representation of the terminal's piping systems and the status of all valves, pumps, and motors. A meter panel provides flow rates, quantities, pressures at the prover loop, meter calibration factors, and print-outs of total quantities. In 1994, the Department plans to replace the Coggins/Intel system with a new state-of-the-art distributed control system.

The Motor Control Center area of the Administration building contains the 4160 volt switchgear and uninterrupted power supply.

Contractor Office Building. This building contains 4,300 square feet of office spaces, including a conference room and lunch room.

Maintenance building. The maintenance building contains a maintenance office area and lunch room, a maintenance shop and housing for the fire truck and its associated equipment.

Spare Parts Warehouse. The St. James warehouse contains 9,000 square feet of space and is used for the storage of spares, repair parts and supplies. The warehouse is protected by a dry pipe sprinkler system.

Oil Quality Assurance Laboratory. The St. James crude oil quality assurance laboratory was constructed in 1986. The laboratory is equipped to perform full crude oil assays, testing for: API gravity, total sulfur by weight, water by distillation, pour point, viscosity, salt content, organic chlorides content, metals by ICP method, vapor pressure, and all other relevant crude oil tests. 


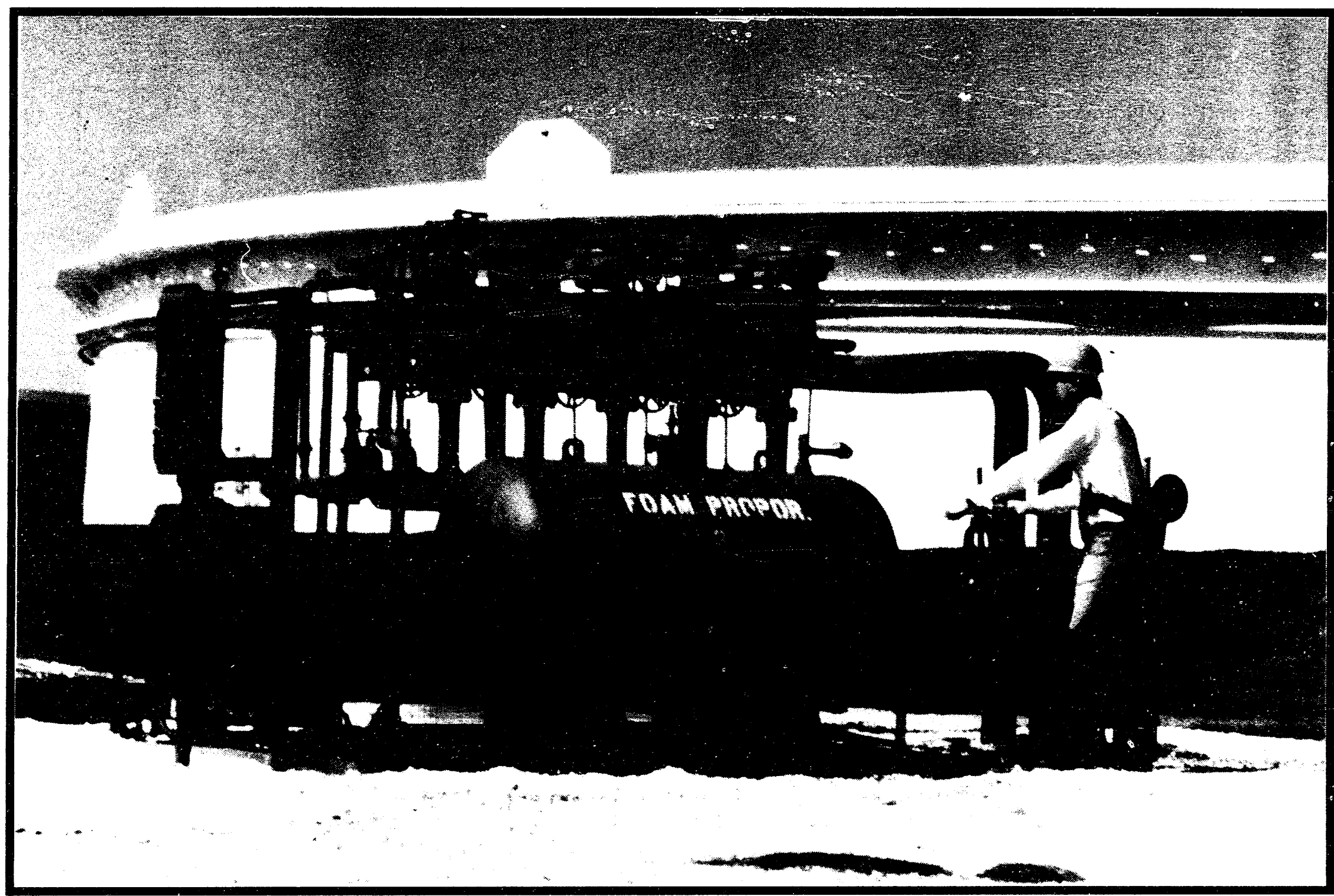

Figure 12: Photograph of Foam Proportioner No. 3

c30002-6 


\section{d. Environmental and Safety Systems}

The terminal and docks have elaborate control systems to prevent fire and environmental contamination from possible spills and accidents.

Fire Protection System: The facility is equipped with a primary fire protection system using potable (City) water and a secondary or backup fire protection system using river water. The primary fire protection system is located at the main terminal and consists of a 400,000 gallon water tank, two 200 horsepower, 1,500 gallon per minute pumps (one electric and one diesel) and a 10 horsepower, 50 gallon per minute jockey pump. These pumps supply pressures of $150 \mathrm{psi}$ to the site's fire protection system.

If conditions warrant an additional water supply, the secondary fire system located on a platform next to Dock 1, will automatically activate. The secondary fire system has two 10,000 gallon per minute pumps (one electric and one diesel), two 1,300 gallon per minute pumps (one electric and one diesel) and a 150 gallon per minute jockey pump. The secondary system is capable of supplying a total of 22,500 gallons per minute as required.

Fire Equipment and Alarms. The terminal is equipped with a 750 gallons per minute pumper fire truck with twin agents: dry chemical and foam. Portable dry-chemical extinguishers are also strategically located throughout the facility for controlling small petroleum and electrical fires. For non-petroleum fires (e.g., fire in buildings or grass areas), both water and fire extinguishers are provided, with hydrants and fire water hose strategicaliy located for this purpose.

Foam system: The St. James terminal has five foam proportioners located throughout the terminal. These proportioners have foam concentrate bladder tanks mixing 3 percent concentrate with 97 percent water and supplying foam to tanks, pumps, and meter stations. The foam system on the oil storage tanks is manually activated in the event of a fire. An automatic activation system is provided for the foam systems at all other locations. Figure 12 is a photograph of the foam proportioners.

Foam Retention Ponds. Two foam retention ponds have been constructed at the terminal to collect foam/water discharged by the fire control foam system. One pond collects foam/water and all storm water from the meter skids area, while the other performs the same function for the booster pumps area. Should the foam/water concentration in either pond exceed allowable limits, it must be disposed of by vacuum truck to appropriate off-site facilities.

Oil Spill Containment System. The terminal and the docks have an oil containment system, which collects any oil spilled during normal operations. All major equipment is connected to a closed loop sump oil system, which has collection tanks and pumps. All oil collected in the system is pumped into the storage tanks. On the docks, a purge pump is used to drain oil from the equipment after which it is pumped to the storage tanks. A similar system of open drains, or in the case of the docks, closed drains, collects rain water and small amounts of spilled oil, which are then pumped to the storage tanks.

Each of the dock platforms have been designed to contain a 666-barrel oil spill before overflowing. Containment equipment is stored at the terminal and includes approximately 2,000 feet of containment boom, and several boats for spill boom deployment and oil spill containment. 


\section{PAGE 17}

The storage tanks are divided into two groups (Tanks 1, 2, 3 and Tanks 4, 5, 6), each of which is surrounded by a dike that can contain the entire volume of crude oil from one tank. The entire terminal site is also surrounded by drainage ditches to carry rainwater from the area into the parish drainage system. The drainage system has four weir gates which prevent spilled oil from leaving the site.

Collection of Oily Waste Discharge. The two docks are also connected to the terminal by a 6-inch line and its attendant pump. Oil waste from the dock platform and runoff is pumped to the terminal for separation. Oil recovered by separation is delivered to the tanks, while the untreated water that meets the environmental permit requirements is discharged through a 20 inch line to Dock 1 and then into the Mississippi River. 


\section{e. Utilities}

The St. James Terminal's facilities for communications, electrical power, potable water, and sanitary wastes are described below.

Communications Systems. The St. James facility has a communications system that ensures close and timely co-ordination of all simultaneous oil transfer operations. In addition to normal public utility communications systems, an internal private communication system allows direct wired communications within the terminal and to the two docks. A master station is located at the operations control console and is connected to nine stations: one at each dock, at the metering stations, and at each of the six crude oil storage tanks.

Electric Power Services. The St. James terminal power requirements are supplied by Louisiana Power and Light Company (LP\&L). Primary feeders bring 34.4 kilovolts, 60-hertz electricity to a LP\&L substation located within the terminal in an area west of the control building. Substation transformers step down the power to a lower voltage prior to feeding the terminal power distribution system. In addition to transformers, the substation contains fused disconnect switches, protective devices, and power meters.

In the event of normal power outages, standby generating facilities automatically supply emergency power. The standby diesel-powered generator provides $480 / 277$ volt, 60 hertz electricity for lighting the control and maintenance building and for closing motor-operated valves in the terminal emergency shutdown system. Upon restoration of the normal power supply, controls automatically transfer the load back to the normal source and stop operation of the standby generator.

Potable Water. Potable water is supplied to the terminal facilities from a St. James Parish water main. Water flows through a 4-inch line to a water meter and then to the Maintenance and Control Center/Office buildings. Potable water is used for drinking fountains, urinals, lavatories, lunchroom, Maintenance/Shop building showers, laboratory sinks, the first aid sink, and the primary fire water tank. Potable water is also supplied through a 2-inch line to each of the two docks.

Sanitation System. Liquid sanitary wastes from the Administration, Contractor Office, Maintenance/Shop, and crude oil laboratory buildings (washwater and sewage) are collected in a sump and then pumped to a packaged chlorination unit for treatment. The treated sewage joins other waste streams en route to wastewater treatment facilities. Following free oil removal, the effluent from these facilities is discharged to the Mississippi River. 


\section{PAGE 19}

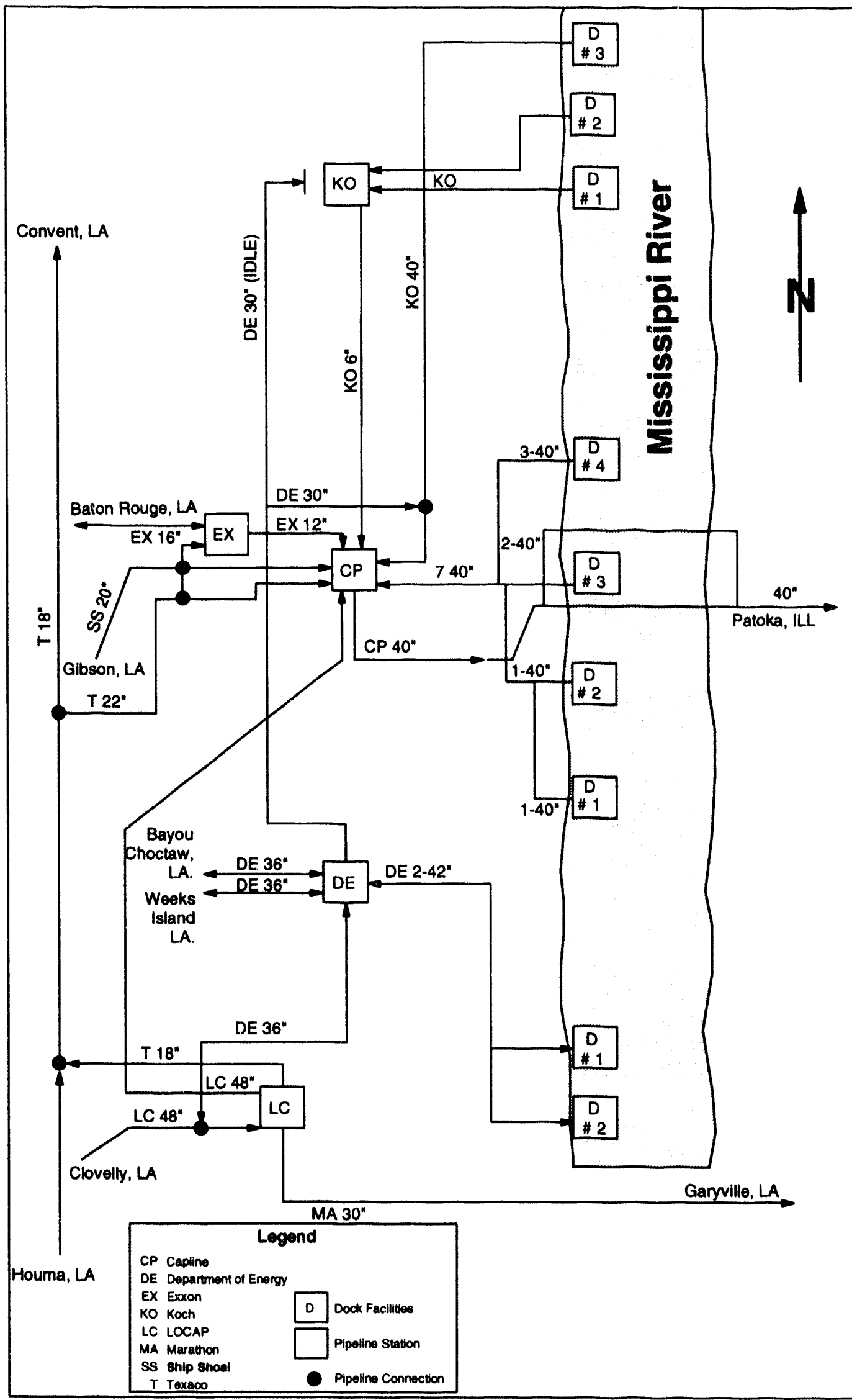

Figure 13. Pipeline Distribution Capability in the St. James Terminal Region 
PAGE 20

\section{OPERATIONAL CAPABILITIES}

The St. James terminal has the capability to both unload and load marine vessels at each of its two docks at rates of up to 40,000 barrels per hour. These two docks are totally independent of each other and capable of simultaneous operations.

In addition to marine capabilities, the St. James terminal has four major crude oil pipelines which connect to other facilities. These are:

(i) 36-inch pipeline to the DOE Bayou Choctaw site.

(ii) 36-inch pipeline to the DOE Weeks Island site.

(iii) 36-inch pipeline to the LOCAP terminal.

(iv) 30-inch pipeline to the Capline and Koch terminals.

These specific pipelines are shown in relation to the other terminals and pipelines in the St. James area in Figure 13. The St. James terminal has the capability to deliver and/or receive crude oil via these pipelines at the rates shown in Table 3.

Table 3

St. James Terminal's Pipeline Distribution Capability (barrels per hour)

\begin{tabular}{|l|c|c|}
\hline \multicolumn{1}{|c|}{ Facility } & Delivery Capability & Receipt Capability \\
\hline $\begin{array}{l}\text { DOE Bayou Choctaw } \\
\text { Site }\end{array}$ & 4,166 (a) & 20,000 (a) \\
\hline Doe Weeks Island Site & 15,000 & $25,000($ a) \\
\hline LOCAP Terminal & 45,000 & 45,000 \\
\hline Capline Terminal & 45,000 & (b) \\
\hline Koch Terminal & (b) & (b) \\
\hline (a) Capability constrained by the specific Site/Terminal served. \\
(b) Capability currently unavailable.
\end{tabular}

The St. James Terminal has the complete flexibility in crude oil receipt and distribution operations. Figure 8 shows the terminal receiving oil from Docks 1 and 2 into tanks 5 and 6 while simultaneously distributing oil from Tanks 1 and 2 to the Capline and Locap Terminals respectively. 


\section{PAGE 21}

\section{TERMINAL CERTIFICATION AND PERMITS}

The Department of Energy received approval from the United States Coast Guard to commence operations at St. James terminal in July 1979.

Since 1988 the St. James terminal has been covered by a Certificate of Adequacy from the U.S. Coast Guard as to its oily waste reception facilities for vessel sludge and oily bilge water wastes. However, the terminal does not have reception facilities for oily ballast. In February 1993, the Department made submissions to the U.S. Coast Guard and the U.S. Environmental Protection Agency for compliance with the Oil Pollution Act of 1990.

The St. James terminal operates under a number of Federal and State issued permits. These permits are listed in Table 4 along with their status.

Table 4

St. James Terminal Permits

\begin{tabular}{||l|c|c|c|c||}
\hline \multicolumn{1}{|c|}{ Permit Obtained } & Permit Number & $\begin{array}{c}\text { Agency Issuing } \\
\text { Permit }\end{array}$ & $\begin{array}{c}\text { Effec- } \\
\text { tive } \\
\text { Date }\end{array}$ & $\begin{array}{c}\text { Expiration } \\
\text { Date }\end{array}$ \\
\hline NPDES & LA0054674 & U.S. EPA & $07 / 11 / 90$ & $07 / 10 / 95$ \\
\hline $\begin{array}{l}\text { NPDES } \\
\text { General Storm Water Permit }\end{array}$ & LAR00A276 & U.S. EPA & $12 / 31 / 92$ & $12 / 31 / 97$ \\
\hline Dredging \& Niaintenance & LMNOD-SP 998 & Corps of Engineers & $03 / 20 / 78$ & $03 / 20 / 88$ \\
\hline Water Discharge & WP 0929 & $\begin{array}{c}\text { LA Dept of Environ. } \\
\text { Quality }\end{array}$ & $05 / 04 / 90$ & $05 / 03 / 95$ \\
\hline Clean Air & 983 & $\begin{array}{c}\text { LA Dept. of } \\
\text { Environ. Quality }\end{array}$ & $07 / 25 / 78$ & Open \\
\hline Permit Exemption & $\begin{array}{c}\text { Conditionally } \\
\text { exempt - small } \\
\text { quantity generator }\end{array}$ & U.S. EPA & & \\
\hline RCRA & & & & \\
\hline
\end{tabular}




\section{GOVERNMENT REQUIREMENTS}

The St. James facility was constructed to provide oil terminaling services for the SPR crude oil storage facilities located at Bayou Choctaw and Weeks Island, Louisiana. The Government will require the St. James terminal to support future oil movement operations in terms of further oil fill requirements (approximately 20 million barrels), annual pipeline inspection and maintenance, periodic system tests and actual emergency drawdown of the Reserve. To the largest extent, these services can be strategically scheduled to allow for uninterrupted crude oil distribution through the dock and terminal into adjacent commercial facilities (LOCAP, Capline, etc.).

The U.S. Government SPR mission must be supported by the St. James facilities including manpower as required to meet any unforeseen emergency drawdown as well as provide for emergency repair and maintenance of the facility. Therefore, any future use of the SPR's St. James facility shall not modify the distribution equipment (pumping, manifolding, and piping, etc.) in any fashion that would detrimentally effect the Government's crude oil movement activities. 







\begin{tabular}{|c|c|c|c|c|c|c|}
\hline Reteronce Number on Map & \multicolumn{3}{|c|}{ Dock Code No. 301} & \multicolumn{3}{|c|}{ Dock Code No. 301} \\
\hline Name & \multicolumn{3}{|c|}{$\begin{array}{l}\text { U.S. Department of Energy } \\
\text { Strategic Petroloum Reserve Dock No. } 1\end{array}$} & \multicolumn{3}{|c|}{ Dock No. 2} \\
\hline Location on Watertront & \multicolumn{3}{|c|}{ Nile 158.3 A.H.P. } & \multicolumn{3}{|c|}{ Mile 158.1 A.H.P. } \\
\hline Owned By & \multicolumn{3}{|c|}{ U.S. Govermment, Department of Energy } & \multicolumn{3}{|c|}{ U.S. Govemment, Department of Energy } \\
\hline Purpose For Which Used & \multicolumn{3}{|c|}{ Receipt of crude oil by vessel } & \multicolumn{3}{|c|}{ Receipt of crude oil by vessel } \\
\hline Type of Construction & \multicolumn{3}{|c|}{$\begin{array}{l}\text { Concrete pile, concrete-decked, off-shore } \\
\text { whart with } 540 \text { - by } 15 \text { - foot part concrete and } \\
\text { part steel pile, concrete-decked approach; } 2 \\
\text { steel breasting platiorms in line with tace and } \\
2 \text { steel mooring dolphins in rear of line of face } \\
\text { on each side, all connected by catwalks. }\end{array}$} & \multicolumn{3}{|c|}{$\begin{array}{l}\text { Concrete pile, concrete-decked, off-shore } \\
\text { whart with } 540 \text { - by } 15 \text {-toot part concrete } \\
\text { and part steel pile, concrele-decked } \\
\text { approach; } 2 \text { steel breasting platforms in line } \\
\text { with face and } 2 \text { steel mooring dolphins in } \\
\text { rear of line of face on each side, all } \\
\text { connected by catwalks. }\end{array}$} \\
\hline Description & Face & Upper Slde & Lower Side & Face & Upper Side & Lower Side \\
\hline Dimensions & 100 & 60 & 60 & 100 & 60 & 60 \\
\hline Depth Alongalde at ALWP & 50 & - & - & 50 & - & - \\
\hline Usabblo Borthing Space & \multicolumn{3}{|c|}{398 w/plats. (Soe Remarks) } & \multicolumn{3}{|c|}{398 w/plats. (Soe Remarks.) } \\
\hline Whath of Apron & 60 & & & 60 & & \\
\hline Holght of Deck Above ALWP & 42 & & & 42 & & \\
\hline Load Cepacity per Sq. F. & - & & & - & & \\
\hline Lighted or Unlighted & \multicolumn{3}{|c|}{ Lighted } & \multicolumn{3}{|c|}{ Lighted } \\
\hline Trensth Shods & \multicolumn{3}{|c|}{ None } & \multicolumn{3}{|c|}{ None } \\
\hline \multicolumn{7}{|l|}{ Number and Type of Construction } \\
\hline \multicolumn{7}{|l|}{ Longth and Wheth $\quad$ (Foot) } \\
\hline \multicolumn{7}{|l|}{ Height haside } \\
\hline Floor Area for Cargo & & & & & & \\
\hline \multicolumn{7}{|l|}{ Load Cepactly per Sq. F. $\quad$ (Lbs.) } \\
\hline \multicolumn{7}{|l|}{ Carge Doore } \\
\hline Mochanical Handing Faclitibs & \multicolumn{3}{|c|}{$\begin{array}{l}\text { Three 16-inch, swivel-jointed unloading ams. } \\
\text { Ore 5-ton, hydraulic crane with } 60 \text {-foot boom } \\
\text { lor handling supplies and equipment }\end{array}$} & \multicolumn{3}{|c|}{$\begin{array}{l}\text { Three 16-inch, swivel-jointed unloading } \\
\text { arms. One } 5 \text {-ton, hydraulic crane with } 60 \text { - } \\
\text { foot boom for handling supplies and } \\
\text { equipment }\end{array}$} \\
\hline Rallway Connections & \multicolumn{3}{|c|}{ None } & \multicolumn{3}{|c|}{ None } \\
\hline Hlghway Connections & \multicolumn{3}{|c|}{$\begin{array}{l}\text { Via road over levee, shell, various widths, from } \\
\text { Louisiana State Highway } 18 \text { (River Road), as- } \\
\text { phatt, } 20 \text { leet wide. }\end{array}$} & \multicolumn{3}{|c|}{ Same as Ref. No. 280} \\
\hline $\begin{array}{l}\text { Water Supply } \\
\text { (Avallable to Vosecto) }\end{array}$ & \multicolumn{3}{|c|}{ Through one 2-inch line. } & \multicolumn{3}{|c|}{ Same as Ret. No. 280} \\
\hline $\begin{array}{l}\text { Electric Current } \\
\text { (Avallable to Vosects) }\end{array}$ & \multicolumn{3}{|c|}{$\begin{array}{l}\text { A.C., } 110 \text { volts, single-phase, } 60 \text {-cycle. A.C., } \\
220 / 440 \text { volts, 3-phase, } 60 \text {-cycle. }\end{array}$} & & lame as Ref. Nc & \\
\hline $\begin{array}{l}\text { Fire Protection } \\
\text { (Other than Clity) }\end{array}$ & 10-ir & $\begin{array}{l}\text { ireline, pump, } h \\
\text { extinguisher }\end{array}$ & and hand & & lame as Ret. Nc & \\
\hline Remerks & $\begin{array}{l}\text { Mooring } \\
\text { vessels. } \\
55-\text { by } 4 \\
\text { pump pla } \\
\text { breasting } \\
\text { tends fro } \\
\text { terminal } \\
\text { rels; } 36-1 \\
\text { the Weel } \\
\text { Choctaw } \\
\text { serves w }\end{array}$ & $\begin{array}{l}\text { hins allow berth } \\
24 \text {-inch water } \\
\text { concrete pile, } \\
\text { n located at rea } \\
\text { form. One } 42- \\
\text { hart to } 6 \text { steel } \\
\text { ar, total capacit } \\
\text { pipelines exten } \\
\text { and SPR site a } \\
\text { i site. One 6-in } \\
\end{array}$ & $\begin{array}{l}\text { of 940-foot } \\
\text { ke and one } \\
\text { lcrete-decked } \\
\text { l upper } \\
\text { ipipeline ex- } \\
\text { ge tanks at } \\
\text { o00,000 bar- } \\
\text { im terminal to } \\
\text { to the Bayou } \\
\text { slops line }\end{array}$ & $\begin{array}{l}\text { Mooring } \\
\text { vessels. } \\
\text { whart to } \\
\text { Ref. No. } \\
\text { whart. }\end{array}$ & $\begin{array}{l}\text { phins allow bert } \\
1042 \text {-inch pipel } \\
\text { rage lacilities de } \\
\text { o. One 6-inch s }\end{array}$ & $\begin{array}{l}\text { g of } 940 \text {-foot } \\
\text { extends from } \\
\text { ribed under } \\
\text { os line serves }\end{array}$ \\
\hline
\end{tabular}

Figure A-1. U.S. Army Corps of Engineers, Port Series, No. 20A, 1981 (modified) 


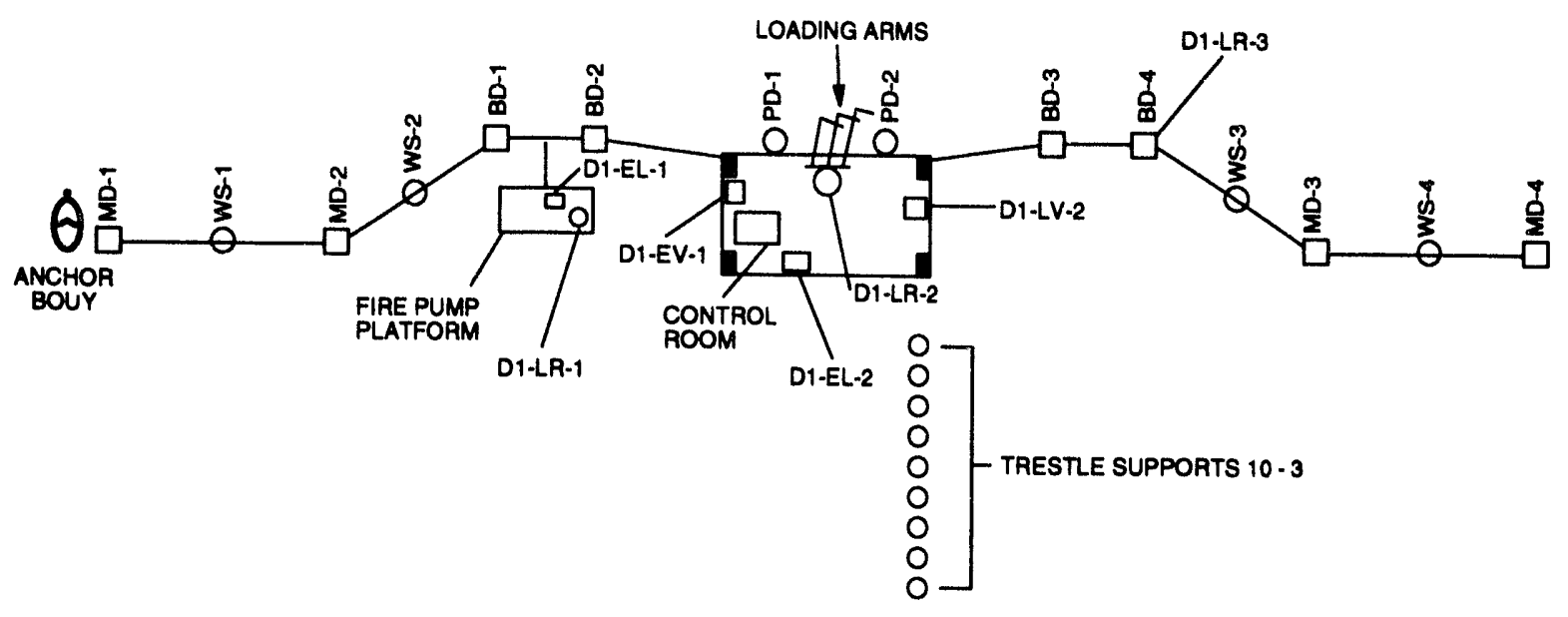

DOCK NO. 1

MLEPOST 158.3

UPSTREAM

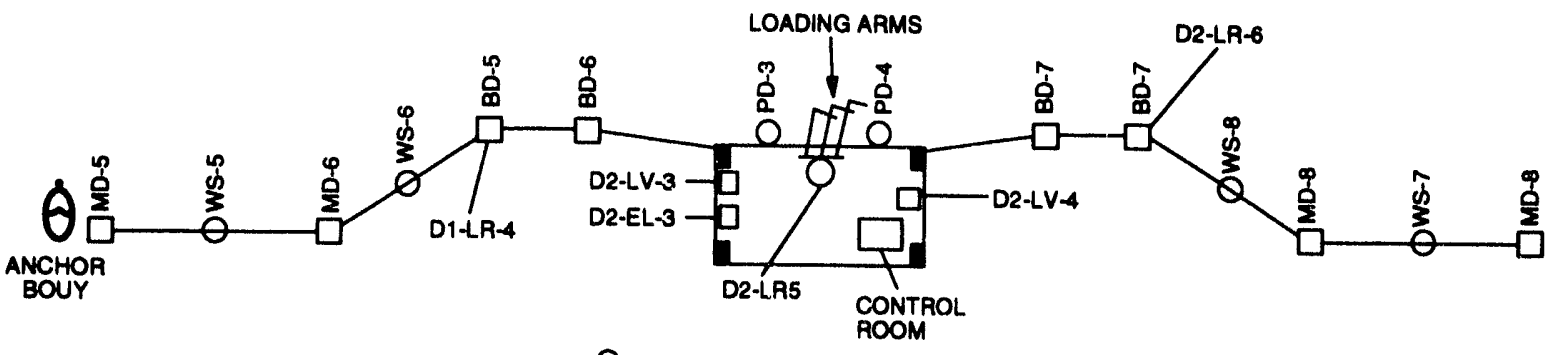

$\left.\begin{array}{l}0 \\ 0 \\ 0 \\ 0 \\ 0 \\ 0 \\ 0\end{array}\right]$ TRESTLE SUPPORTS $26 \cdot 21$

DOCK NO. 2

MLEPOST 158.0

NOTES

CONTROL ROOMS ARE PRESSURIZED AND HAVE AVAILABLE:

LEGEND

- fIRST AID KITS

- SELF-CONTAINED BREATHING APPARATUS UNITS

- COMBUSTIBLE DETECTORS

- BASKET STRETCHERS

MD = MOORING DOLPHIN

WS = WALKWAY SUPPORT

$B D=$ BREASTING DOLPHIN

$P D=$ PROTECTIVE DOLPHIN

LR = LIFE RING

$L V=$ LIFE VEST

$E L=E M E R G E N C Y$ LADDERS

Figure A-2. Detailed Schematic of the St. James Terminal Docks 


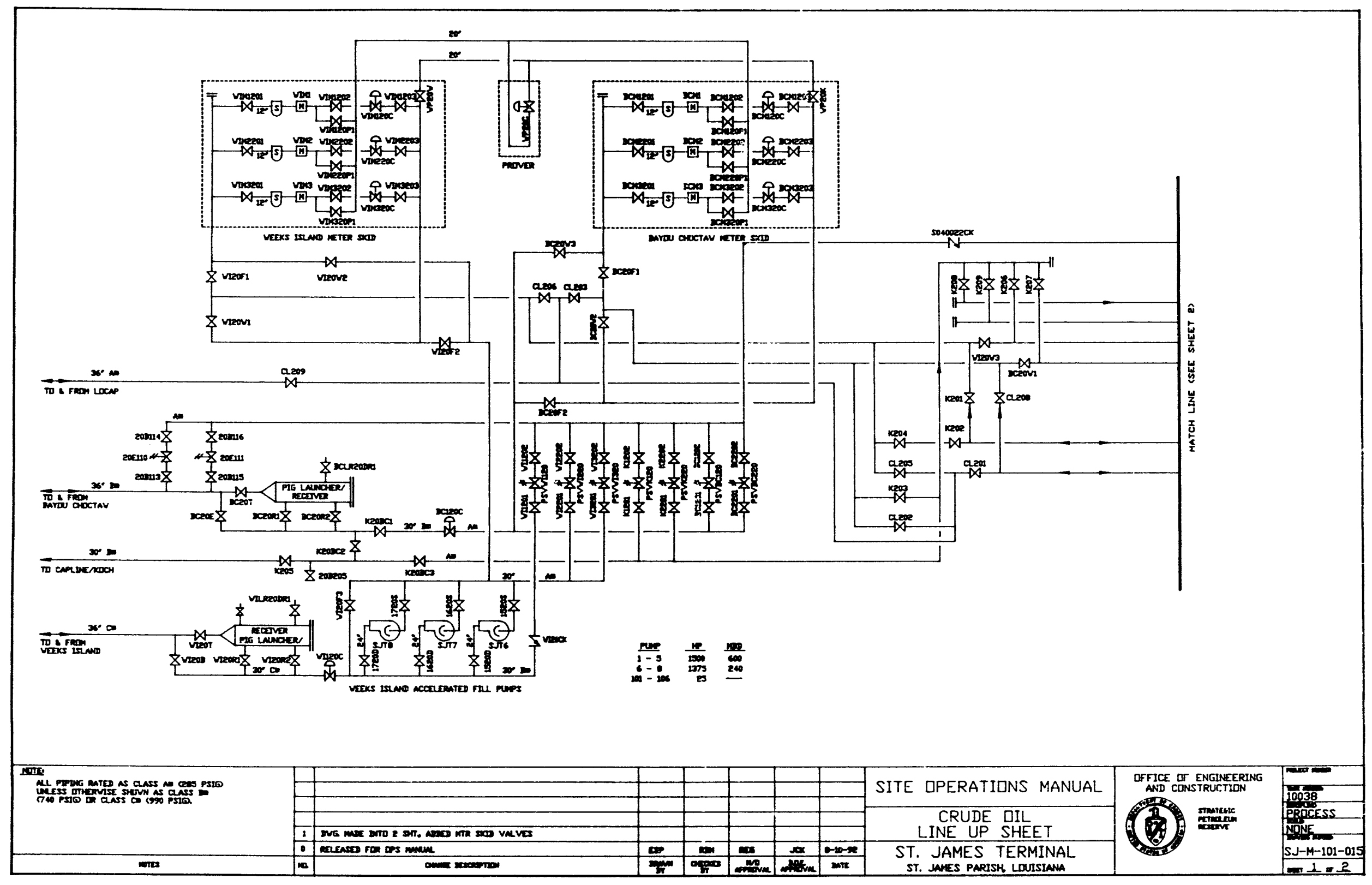

Figure A-3 Schematic of Piping and Values at St. James Terminal 


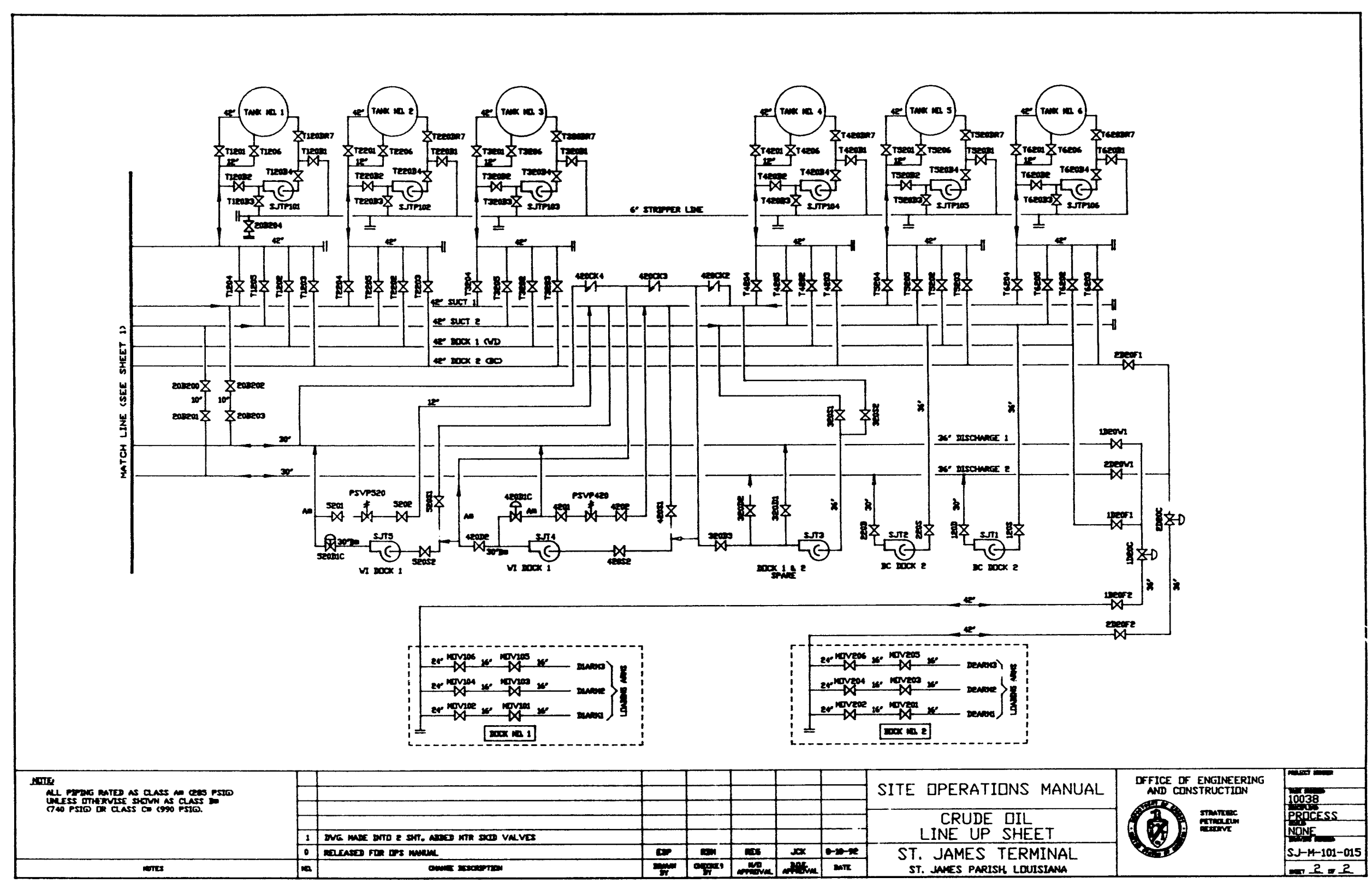

Figure A-3 Schematic of Piping and Values at St. James Terminal (continued) 


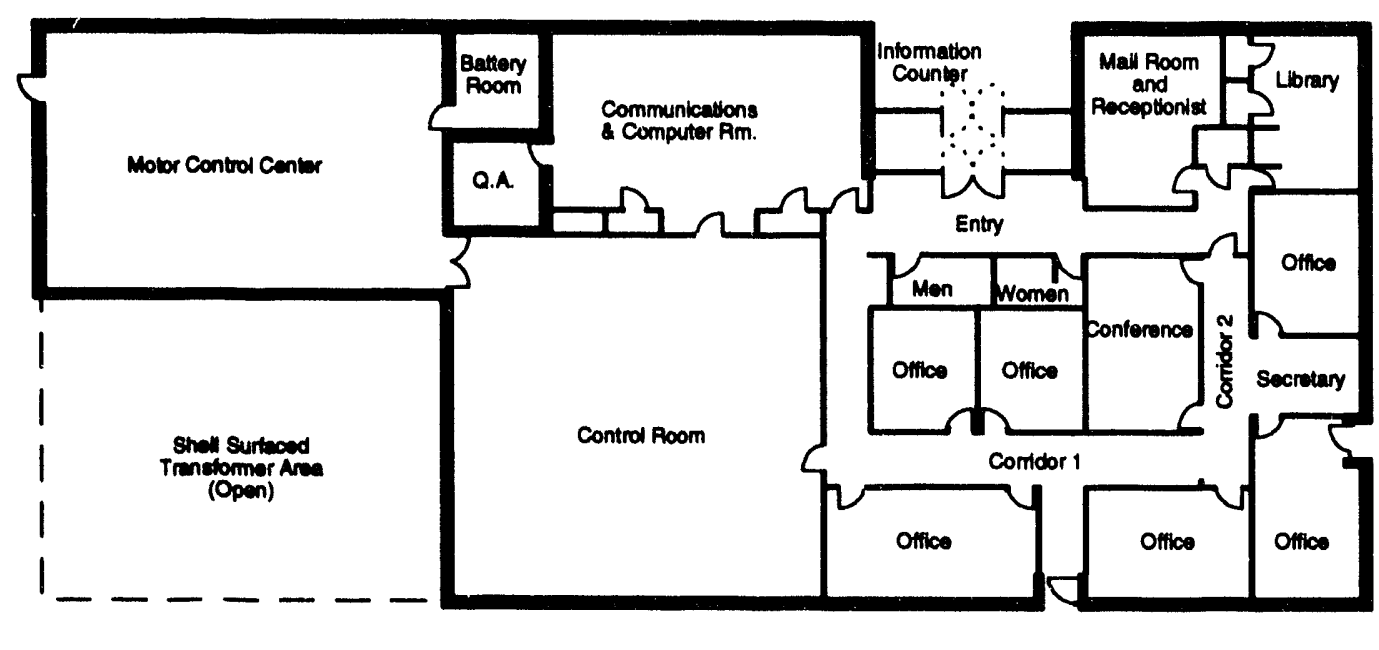

Administration Bullding/Control Conter

(150 ft $\times 64 \mathrm{ft}$ )

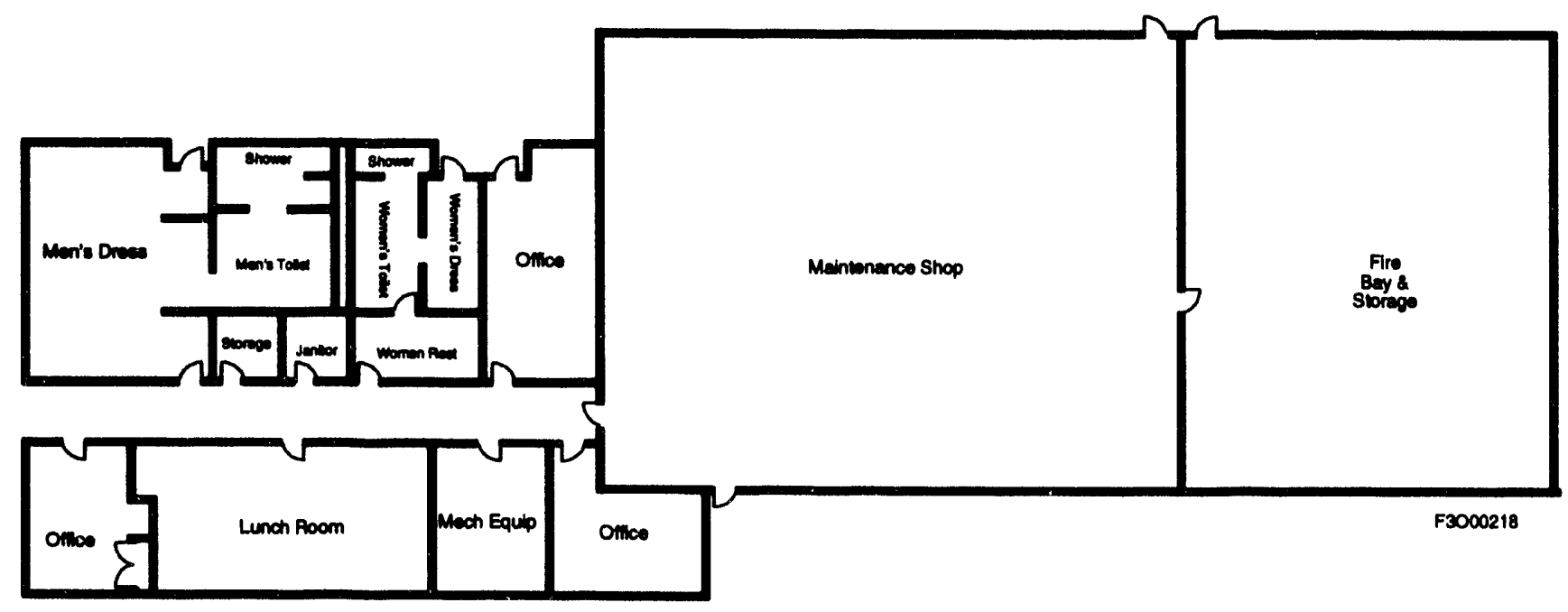

Malntenance Bullding/Shop

(166 ft $\times 49 \mathrm{ft}$ )

Figure A-4. Detalls of Main Bulldings at St. James Terminal 


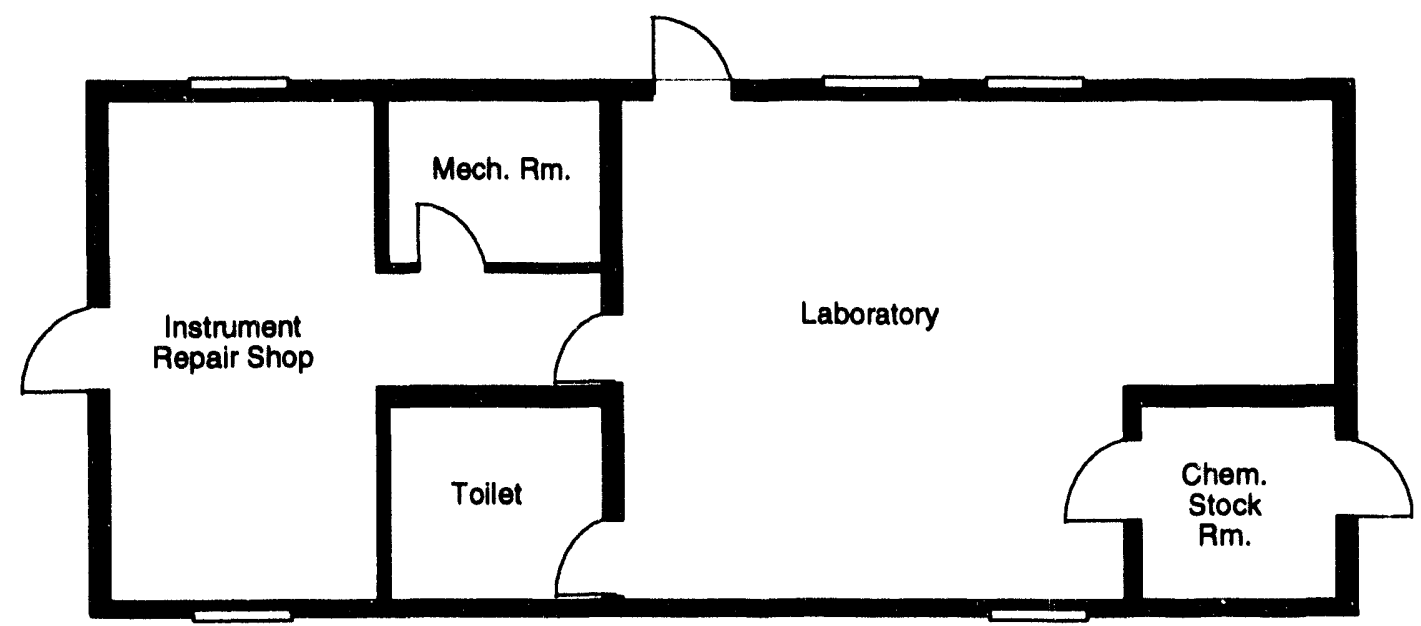

Crude Oil Quality Assurance Laboratory

(52 ft x 22 ft)

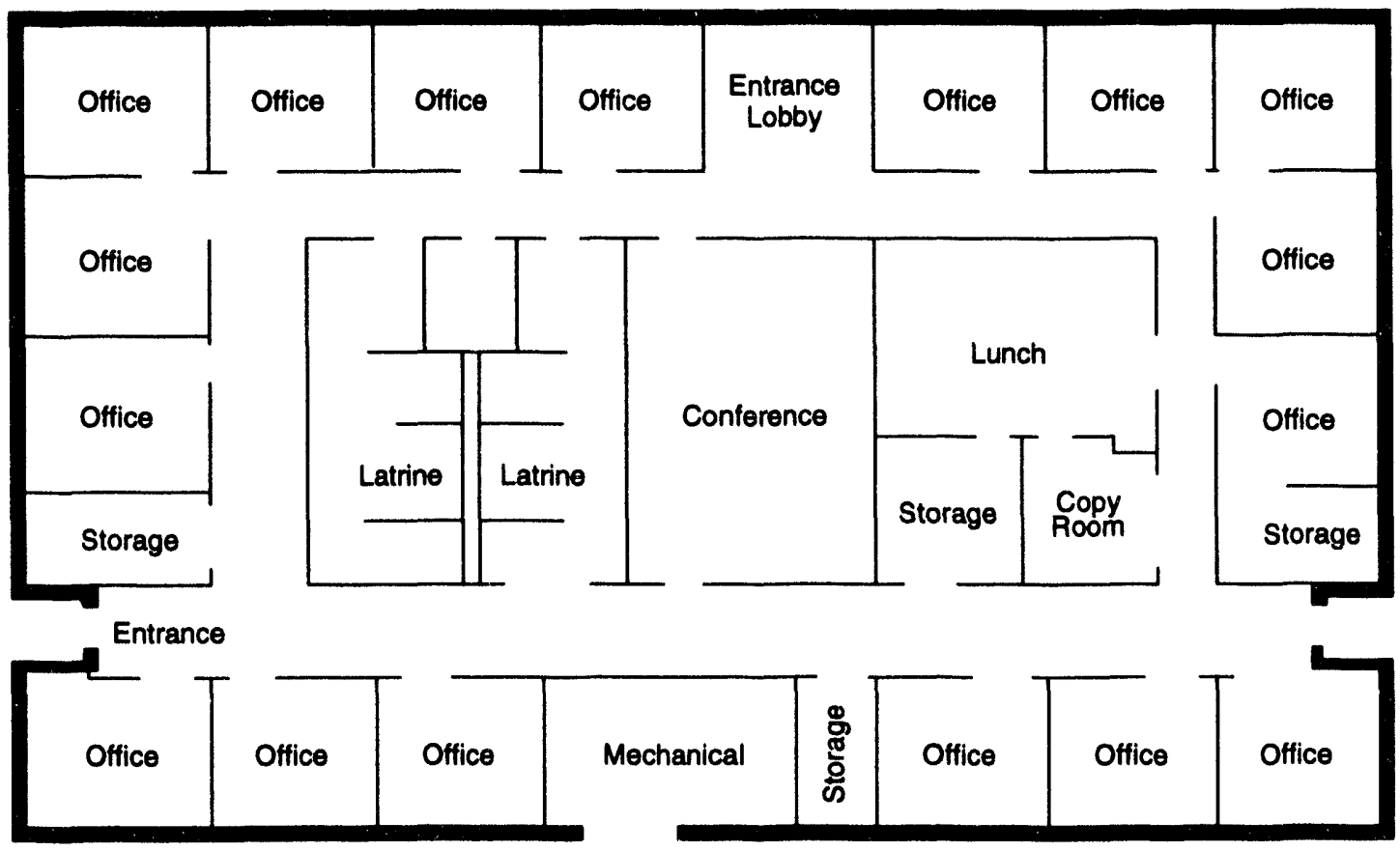

Contracter Office Building

(83 ft x 52 ft)

Figure A-4. Detalls of Main Buildings at St. James Terminal (continued) 


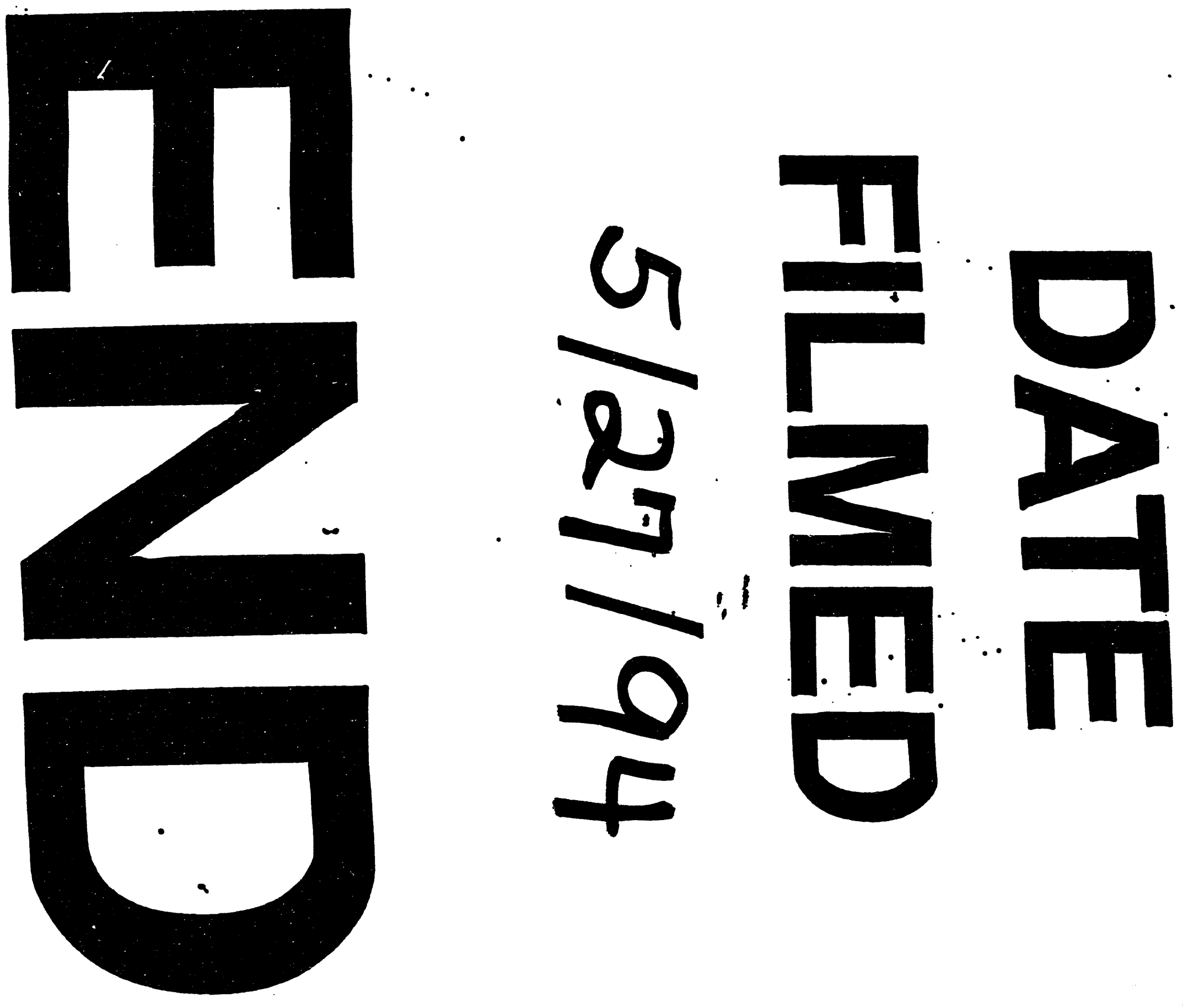


